\title{
VALIDASI METODE ANALISIS ASAM LEMAK TRANS DALAM MAKANAN BERDASARKAN AOCS OFFICIAL METHOD Ce 1h-05
}

\author{
[Validation of Trans Fatty Acid in Foods Analysis Method Based on \\ AOCS Official Method Ce 1h-05]
}

\author{
Maria Fransisca Njoman ${ }^{1)}$, dan Nuri Andarwulan ${ }^{1,2) \star ~}$ \\ 1) Departemen Ilmu dan Teknologi Pangan, Fakultas Teknologi Pertanian, Institut Pertanian Bogor, Bogor \\ 2) Southeast Asian Food and Agricultural Science and Technology Center, Institut Pertanian Bogor, Bogor
}

Diterima 14 Februari 2016 / Disetujui 06 Juni 2016

\begin{abstract}
Cardiovascular disease is related to the high consumption of trans fatty acid. This issue has driven SEAFAST IPB Laboratory to develop a trans fatty acid analysis method for gas chromatography based on AOCS Official Method Ce 1h-05. This research was aimed to validate the method via three steps: preparation step, procedure orientation test, and method validation. During instrument performance testing in the preparation step, linearity, limit of detection ( $L O D)$, limit of quantitation (LoQ), range, and precision parameters were validated for FAME 9t-C18:1 and C18:2 isomer mixed standard solution. During the method validation step, specificity, precision and accuracy parameters were validated for 9t-C18:1 compound attached to food matrix, i.e. doughnut. The instrument validation result of 9t-C18:1 standard solution had fulfilled the criteria of linearity $\left(r^{2}=1\right.$, requirement $\left.r^{2}>0.990\right)$ within the range of 0.0020 to $0.1200 \mathrm{mg} / \mathrm{mL}$; precision (RSD) $0.24 \%$; LoD $0.0007 \mathrm{mg} / \mathrm{mL}$ and LoQ $0.0020 \mathrm{mg} / \mathrm{mL}$. The instrument validation result for each isomer in C18:2 standard solution also met the criteria of linearity $\left(r^{2}=0.9999\right.$, requirement $r^{2}>0.990$ ) with precision (RSD), LoD and LoQ respectively; 1) 9t,12t-C18:2: 1.40\%;0.0033 $\mathrm{mg} / \mathrm{mL} ; 0.0100 \mathrm{mg} / \mathrm{mL}$; 2) 9t,12c-C18:2: $1.89 \% ; 0.0015 \mathrm{mg} / \mathrm{mL} ; 0.0045 \mathrm{mg} / \mathrm{mL}$; 3) 9c,12t-C18:2: 2.39\%; $0.0015 \mathrm{mg} / \mathrm{mL} ; 0.0044 \mathrm{mg} / \mathrm{mL}$; 4) C18:2 cis: $3.39 \% ; 0.0006 \mathrm{mg} / \mathrm{mL} ; 0.0019 \mathrm{mg} / \mathrm{mL}$. The validation result for 9t-C18:1 in $100 \mathrm{mg}$ fat extract of doughnut suggested that the modified method is validated in term of specificity $(R s=1.2)$, precision $(R S D$ fatty acid content $(\mathrm{mg} / \mathrm{g})=1.78 \% ; R S D$ percentage of fatty acid content towards total fatty acid $=0.72 \%$ ) and accuracy (as percentage of recovery) $80.54-94.25 \%$.
\end{abstract}

Keywords: gas chromatography, method validation, trans fatty acid

\section{ABSTRAK}

Meningkatnya isu kesehatan terkait penyakit kardiovaskuler yang dihubungkan dengan tingkat konsumsi asam lemak trans mendorong laboratorium SEAFAST IPB untuk mengembangkan metode analisis asam lemak trans dengan kromatografi gas berdasarkan AOCS Official Method Ce 1h-05 (AOCS, 2005). Penelitian ini bertujuan untuk memvalidasi metode tersebut melalui tiga tahap: tahap persiapan, orientasi prosedur uji dan validasi metode. Selama pengecekan unjuk kerja instrumen pada tahap persiapan dilakukan validasi linieritas, batas deteksi $(L O D)$ dan batas kuantitasi $(L O Q)$, rentang kerja, serta presisi pada larutan baku FAME 9t-C18:1 dan campuran isomer C18:2. Sementara pada tahap validasi metode dilakukan validasi spesifisitas, presisi dan akurasi untuk senyawa $9 \mathrm{t}-\mathrm{C} 18: 1$ dalam matriks produk pangan, dalam hal ini donat. Hasil validasi instrumen pada baku 9t-C18:1 memenuhi kriteria linieritas $\left(\mathrm{r}^{2}=\right.$ 1,00 , syarat $\left.r^{2}>0,990\right)$ pada rentang kerja 0,0020 sampai $0,1200 \mathrm{mg} / \mathrm{mL}$, dengan presisi $(R S D) 0,24 \%$, LoD $0,0007 \mathrm{mg} / \mathrm{mL}$, dan $L o Q 0,0020 \mathrm{mg} / \mathrm{mL}$. Hasil validasi untuk setiap isomer dalam baku campuran isomer C18:2 juga memenuhi kriteria linieritas $\left(r^{2}=0,9999\right.$, syarat $\left.r^{2}>0,990\right)$ dengan presisi $(R S D), L O D$ dan LoQ masing-masing; 1) 9t,12t-C18:2: 1,40\%; 0,0033 mg/mL 0,0100 mg/mL; 2) 9t,12c-C18:2: 1,89\%; $0,0015 \mathrm{mg} / \mathrm{mL} ; 0,0045 \mathrm{mg} / \mathrm{mL}$; 3) 9c,12t-C18:2: 2,39\%; 0,0015 mg/mL; 0,0044 mg/mL; 4) C18:2 cis: $3,39 \% ; 0,0006 \mathrm{mg} / \mathrm{mL} ; 0,0019 \mathrm{mg} / \mathrm{mL}$. Hasil validasi metode untuk senyawa $9 \mathrm{t}-\mathrm{C} 18: 1$ dalam $100 \mathrm{mg}$ ekstrak lemak donat menunjukkan bahwa metode tervalidasi untuk parameter spesifisitas $(R s=1,2)$, presisi $(R S D$ kadar asam lemak $(\mathrm{mg} / \mathrm{g})=1,78 \% ; R S D$ persen kadar asam lemak terhadap asam lemak total $=0,72 \%$ ) dan akurasi (persen rekoveri) $80,54-94,25 \%$.

Kata kunci: asam lemak trans, kromatografi gas, validasi metode

*Penulis Korespondensi:

E-mail: nuri@seafast.org 


\section{PENDAHULUAN}

Peningkatan konsumsi asam lemak trans (ALT) berbanding lurus dengan peningkatan prevalensi penyakit jantung koroner (corronary heart disease, $C H D$ ), diabetes mellitus tipe 2, gangguan saraf dan ingatan, apoptosis sel endotel serta obesitas (De Souza et al., 2015; Ganguly dan Pierce, 2015). Berdasarkan hasil penelitian Harvey et al. (2008), dan Xu et al. (2006), konsumsi ALT memiliki korelasi positif dengan peningkatan risiko atherosklerosis. Hal ini didukung oleh data Mosley et al. (2005) yang menunjukkan kelompok orang dengan asupan ALT 5,7 g/hari memiliki risiko $C H D \quad 50 \%$ lebih tinggi dibandingkan kelompok yang mengonsumsi 2,4 g/hari. Asam lemak jenuh dan ALT sama-sama meningkatkan rasio low density lipoprotein/high density lipoprotein ( $L D L / H D L)$ yang memicu $C H D$ (Gebauer et al., 2015; Siri-Tarino et al., 2010), namun efek negatif yang ditimbulkan ALT mendekati dua kali lebih besar dibandingkan asam lemak jenuh karena asam lemak jenuh hanya meningkatkan kadar $L D L$, sementara ALT meningkatkan kadar $L D L$ dan juga mengurangi $H D L$ dalam darah (Sartika, 2008; Hunter et al., 2010). Pada tingkat berlebih, ALT dapat menginduksi penyakit diabetes mellitus tipe 2. dengan menurunkan sensitivitas insulin (Hamilton et al., 2015; Kavanagh et al., 2007). Kelebihan ALT disimpan dalam jaringan lemak yang dalam jangka panjang dapat terakumulasi dan menyebabkan obesitas (Stachowska et al., 2010).

Sekitar 80-90\% konsumsi ALT berasal dari produk hidrogenasi parsial, seperti margarin, shortening, dan deep frying fats, sementara sisanya berasal dari sumber alami hewan ruminansia (Sartika, 2008; Zhang et al., 2015). Hidrogenasi adalah proses penambahan atom hidrogen pada ikatan rangkap asam lemak tidak jenuh sehingga mengubahnya menjadi asam lemak jenuh (Vahmani et al., 2015). Proses ini bertujuan untuk meningkatkan titik leleh minyak nabati sehingga bewujud padat pada suhu ruang. Selain meningkatkan derajat kejenuhan minyak nabati, proses hidrogenasi berpotensi menginduksi isomerisasi pada asam lemak tidak jenuh yang alaminya berbentuk cis menjadi trans. Produk dominan hasil isomerisasi ini adalah senyawa 9t-C18:1 yang lebih sulit dimetabolisme dan memiliki prevalensi terakumulasi dalam sel lebih tinggi dibandingkan ALT alami (Vahmani et al., 2015). Produk isomerisasi lainnya adalah 9t,12tC18:2 yang memiliki dampak lebih besar terhadap peningkatan risiko $C H D$ dibandingkan 9t-C18:1 (Sun, 2007; Merchant et al., 2008). Mengingat tingginya risiko kesehatan akibat konsumsi ALT, pada Januari 2006, US Food and Drug Administration (FDA) merilis final rule tentang pelabelan ALT pada produk pangan yang menyatakan bahwa jumlah asam lemak trans dalam satu kali penyajian dicantumkan dalam satu baris terpisah persis di bawah lemak jenuh (Delmonte dan Rader, 2007). Profil asam lemak dapat dianalisis menggunakan metode spektroskopi IR, kromatografi gas (KG), spektroskopi resonansi magnetik karbon nuklir, kromatografi lapis tipis, atau High Performance Liquid Chromatography (HPLC) (Delmonte dan Rader, 2007). Kromatografi gas merupakan metode yang paling banyak digunakan, karena kemampuannya memisahkan asam lemak dalam jumlah besar (Delmonte dan Rader, 2007; Song et al., 2015).

Analisis profil asam lemak dengan KG sudah diterapkan di laboratorium Southeast Asia Food and Agriculture Science and Technology (SEAFAST) IPB menggunakan kolom DB-23 (Supelco, USA) dengan acuan AOAC Official Method 991.39 termodifikasi, namun kolom dan metode ini tidak ditujukan untuk analisis ALT. Oleh karena itu SEAFAST mengadopsi metode analisis ALT yang diakui secara internasional yaitu AOCS Official Method Ce 1h-05 (AOCS, 2005). Pelaksanaan metode ini terkendala oleh tidak tersedianya kolom yang diminta, yaitu kolom kapiler SP-2560 atau CPSil 88. Ketidaktersediaan kolom tersebut diatasi dengan penggunaan kolom SP-2340 yang dirujuk oleh AOAC Official Method 996.06 (AOAC, 2000). Perbedaan kapabilitas dan kapasitas kolom serta instrumen $\mathrm{KG}$ yang digunakan di laboratorium SEAFAST menuntut dilakukannya modifikasi metode untuk penyesuaian. Sebelum diaplikasikan, mtode termodifikasi perlu divalidasi untuk menjamin performa data hasil analisis. Penelitian ini bertujuan untuk memvalidasi metode analisis ALT hasil modifikasi AOCS Official Method Ce 1h-05 agar dapat diterapkan di laboratorium SEAFAST.

\section{BAHAN DAN METODE}

\section{Bahan}

Bahan yang digunakan adalah donat, baku metil ester asam lemak (fatty acid methyl esther, FAME) campuran (C8-C22) $25 \mathrm{mg} / \mathrm{ml}$ dalam larutan metilena klorida (Supelco), baku FAME 9t-C18:1 (Supelco), baku FAME campuran isomer C18:2 (9t,12t-C18:2 (50\%); 9c,12t-C18:2 (20\%); 9t,12cC18:2 (20\%); dan C18:2 cis (10\%) (Sigma-Aldrich), asam margarat sebagai baku internal (Sigma Aldrich).

\section{Tahap persiapan}

Tahap persiapan meliputi penyiapan larutan baku eksternal dan pengecekan unjuk kerja instrumen KG. Larutan baku eksternal terdiri dari FAME campuran isomer C18:2 yang di dalamnya mengandung 9t,12t-C18:2 (50\%); 9c,12t-C18:2 (20\%); 9t,12c-C18:2 (20\%); dan C18:2 cis (10\%). Larutan 
baku FAME campuran isomer C18:2 dengan konsentrasi $25 \mathrm{mg} / \mathrm{mL}$ dalam metilena klorida diencerkan menjadi $2,5 \mathrm{mg} / \mathrm{mL}$ dengan pelarut heksana, lalu dicampurkan dengan larutan baku FAME campuran (C8-C22) konsentrasi $10 \mathrm{mg} / \mathrm{mL}$ dalam heksana dengan perbandingan 1:1. Larutan baku eksternal dianalisis dengan kromatografi (KG2100 Series, Shimadzu Cor-poration, Japan) untuk mengidentifikasi waktu retensi dan nilai response factor $(R F)$ masing-masing asam lemak dalam baku eksternal.

$$
\mathrm{Alx}=\frac{\mathrm{Aalx}}{\mathrm{ASI}} \times \frac{\mathrm{BSI}}{\mathrm{BS}} \times \mathrm{RF} \times 100
$$

Keterangan:

$\mathrm{Alx}=$ konsentrasi asam lemak tertentu dalam contoh $(\mathrm{mg} / \mathrm{g})$

Aalx = area asam lemak tertentu pada kromatogram contoh

ASI = area baku internal pada kromatogram contoh

$\mathrm{BSI}=$ berat baku internal yang ditambahkan pada contoh (mg)

BS = berat contoh yang dimetilasi $(\mathrm{mg})$

$\mathrm{RF} \quad=$ Response Factor

$$
\mathrm{RF}=\frac{\mathrm{ASI}}{\mathrm{Aalx}} \times \frac{\mathrm{Balx}}{\mathrm{BSI}}
$$

Keterangan:

$\mathrm{RF} \quad=$ Response Factor

$\mathrm{ASI}=$ area baku internal pada kromatogram baku eksternal

Aalx = area asam lemak tertentu pada kromatogram baku eksternal

$\mathrm{BSI}=$ konsentrasi baku internal dalam komposisi baku eksternal

Balx = konsentrasi asam lemak dalam komposisi baku eksternal

Pengecekan unjuk kerja instrumen KG dilakukan untuk melihat kinerja instrumen dan menentukan modifikasi metode yang akan divalidasi pada tahap selanjutnya. Metode analisis mengacu pada AOCS Official Method Ce 1h-05 yang terdiri dari tiga tahapan yaitu tahap ekstraksi lemak, derivatisasi asam lemak dan analisis KG. Metode ekstraksi lemak dan derivatisasi asam lemak yang dirujuk oleh AOCS Official Method Ce 1h-05 adalah AOCS Official Method Ce 2-66 (AOCS, 1997). Metode ekstraksi diubah menjadi metode Folch et al. (1957), sementara metode derivatisasi dimodifikasi pada parameter volume dan rasio reagen (Tabel 1). Metode analisis KG dimodifikasi pada parameter pengaturan gas pembawa, suhu kolom, suhu detektor, kolom kapiler, dan nisbah pemecahan dalam mode injeksi. Modifikasi metode secara lengkap dapat dilihat pada Tabel 2, sementara kondisi operasional KG secara lengkap dapat dilihat pada Tabel 3. metode ini dipilih berdasarkan pertimbangan efisiensi dan kemudahan penerapannya di laboratorium.
Tabel 1. Modifikasi metode derivatisasi asam lemak

\begin{tabular}{lcc}
\hline \multicolumn{1}{c}{ Parameter } & $\begin{array}{c}\text { AOCS Official } \\
\text { Method Ce-2 66 }\end{array}$ & $\begin{array}{c}\text { Metode } \\
\text { Modifikasi }\end{array}$ \\
\hline Massa sampel & $100-250 \mathrm{mg}$ & $100 \mathrm{mg}$ \\
Volume NaOH & $4 \mathrm{~mL}$ & $2 \mathrm{~mL}$ \\
$0,5 \mathrm{~N}$ & $5 \mathrm{~mL}$ & $2 \mathrm{~mL}$ \\
$\begin{array}{l}\text { Volume BF3- } \\
\text { metanol }\end{array}$ & $15 \mathrm{~mL}$ & $3 \mathrm{~mL}$ \\
$\begin{array}{l}\text { Volume NaCl } \\
\text { jenuh }\end{array}$ & $2-5 \mathrm{~mL}$ heptana & $1,5 \mathrm{~mL}$ heksana \\
Pelarut &
\end{tabular}

Tabel 2. Modifikasi metode analisis asam lemak

\begin{tabular}{|c|c|c|}
\hline Parameter & AOCS Ce1h-05 & Metode Modifikasi \\
\hline $\begin{array}{l}\text { Derivatisasi } \\
\text { asam lemak }\end{array}$ & AOCS Ce 2-66 & $\begin{array}{l}\text { AOCS Ce 2-66 } \\
\text { termodifikasi }\end{array}$ \\
\hline Suhu kolom & Isotermal $180^{\circ} \mathrm{C}$ & $\begin{array}{l}\text { Terprogram } \\
\text { Suhu awal: } 120^{\circ} \mathrm{C} \\
\text { (6 menit), laju: } \\
3^{\circ} \mathrm{C} / \text { menit, } \\
\text { Suhu akhir: } 230^{\circ} \mathrm{C} \\
\text { (25 menit) }\end{array}$ \\
\hline $\begin{array}{l}\text { Suhu } \\
\text { injektor }\end{array}$ & $250^{\circ} \mathrm{C}$ & $250^{\circ} \mathrm{C}$ \\
\hline $\begin{array}{l}\text { Suhu } \\
\text { detektor }\end{array}$ & $250^{\circ} \mathrm{C}$ & $260^{\circ} \mathrm{C}$ \\
\hline $\begin{array}{l}\text { Kolom } \\
\text { kapiler }\end{array}$ & $\begin{array}{l}\text { Fused silica } \\
\text { capillary, SP-2560 } \\
\text { phase (Supelco) } \\
\text { atau CP-Sil } 88 \\
\text { (Chrompack), } 100 \\
\mathrm{~m} \times 0,25 \mathrm{~mm}, \\
\text { ketebalan film } 0,20 \\
\mu m\end{array}$ & $\begin{array}{l}\text { Fused silica } \\
\text { capillary, SP-2340 } \\
\text { phase, panjang } 60 \\
\mathrm{~m} \text {, diameter } \\
\text { dalam } 0,25 \mathrm{~mm}, \\
\text { ketebalan film } \\
0,20 \mu \mathrm{m} \text { (Supelco) }\end{array}$ \\
\hline $\begin{array}{l}\text { Gas } \\
\text { pembawa }\end{array}$ & $\begin{array}{l}\text { He, tekanan: } 286 \\
\text { kPa, laju alir: } 1,0 \\
\text { mL/menit, } \\
\text { kecepatan linier: } \\
19 \mathrm{~cm} / \mathrm{s}\end{array}$ & $\begin{array}{l}\text { He, tekanan: } \\
165,9 \mathrm{kPa} \text {, laju } \\
\text { alir: } 1,0 \mathrm{~mL} / \mathrm{menit} \text {, } \\
\text { kecepatan linier: } \\
23,1 \mathrm{~cm} / \mathrm{s}\end{array}$ \\
\hline Mode injeksi & $\begin{array}{l}\text { Split injection } \\
(100: 1)\end{array}$ & $\begin{array}{l}\text { Split injection } \\
(30: 1)\end{array}$ \\
\hline
\end{tabular}
trans

Pada tahap pengecekan unjuk kerja instrumen dilakukan uji linieritas, presisi, rentang kerja, batas deteksi (Limit of Detection, LoD) dan batas kuantitasi (Limit of Quantitation, LoQ) untuk larutan baku FAME 9t-C18:1 dan baku FAME campuran isomer C18:2. Pada uji linieritas, masing-masing larutan baku dibuat dalam lima konsentrasi. Pemilihan konsentrasi terendah dilakukan dengan uji coba sehingga diperoleh konsentrasi dengan luas area yang terdeteksi cukup baik dan dapat terukur oleh KG. Larutan baku 9t-C18:1 dibuat dengan konsentrasi 0,$0040 ; 0,0100 ; 0,0400 ; 0,0500$; dan $0,1000 \mathrm{mg} / \mathrm{mL}$, sementara larutan baku C18:2 dibuat dengan konsentrasi 0,0025; 0,0050; 0,0100; 0,0250 ; dan $0,7500 \mathrm{mg} / \mathrm{mL}$. Validasi linieritas dilakukan untuk memetakan hubungan antara konsentrasi senyawa analit, sebagai sumbu $\mathrm{x}$, dengan luas area, sebagai sumbu y. Suatu metode dikatakan memiliki 
linieritas yang baik apabila persamaan kurva memiliki koefisien korelasi $r>0,995$ atau $r^{2}>0,990$ (AOAC, 2012). Selanjutnya berdasarkan analisis data simpangan baku $(\sigma)$ dan kemiringan kurva (S) dari kurva linieritas, dianalisislah nilai $\operatorname{LoD}(3,3 \mathrm{\sigma} / \mathrm{S})$ dan $\operatorname{LoQ}(10 \mathrm{\sigma} / \mathrm{S})(\mathrm{ICH}, 2005)$. Karena akan digunakan pada tahap validasi metode untuk sampel, nilai rentang kerja juga ditentukan untuk senyawa 9tC18:1, di mana berdasarkan panduan validasi metode Eurachem (Magnusson dan Ornemark, 2014) nilai batas bawah diperoleh dari hasil perhitungan LoQ, sementara batas atas ditentukan pada konsentrasi $20 \%$ lebih tinggi dibandingkan konsentrasi tertinggi pada uji linieritas.

Tabel 3. Kondisi operasional KG

\begin{tabular}{|c|c|}
\hline Komponen & Deskripsi \\
\hline Instrumen & KG-2100 Series Shimadzu \\
\hline utama & Corporation \\
\hline Monitor panel & Hewlett Packard Flat Panel Monitor \\
\hline Kolom & $\begin{array}{l}\text { Fused silica capillary, SP-2340, } \\
\text { panjang } 60 \mathrm{~m} \text {, diam eter dalam } 0,25 \\
\mathrm{~mm} \text {, ketebalan film } 0,20 \mu \mathrm{m}\end{array}$ \\
\hline Detektor & Flame Ionization Detector(FID) \\
\hline Penyuntik & SGE, Penyuntik mikro $10 \mu \mathrm{L}$ \\
\hline Gas pembawa & $\begin{array}{l}\text { Helium (kemurnian 99,999\%, Global } \\
\text { Gases Indonesia) }\end{array}$ \\
\hline $\begin{array}{l}\text { Laju alir gas } \\
\text { pembawa }\end{array}$ & $1,00 \mathrm{~mL} / \mathrm{menit}$ \\
\hline Make upgas & $\mathrm{N}_{2}(\mathrm{UHP}$, Alphagaz) \\
\hline Make up flow & $30,0 \mathrm{~mL} / \mathrm{menit}$ \\
\hline Aliran $\mathrm{H}_{2}$ & 40,0 mL/menit \\
\hline Aliran udara & $400,0 \mathrm{~mL} /$ menit \\
\hline Volume injeksi & $1 \mu \mathrm{L}$ \\
\hline Suhu detektor & $260^{\circ} \mathrm{C}$ \\
\hline Suhu injektor & $250^{\circ} \mathrm{C}$ \\
\hline
\end{tabular}

Salah satu konsentrasi dari lima konsentrasi larutan dalam uji linieritas digunakan untuk validasi instrumen parameter presisi. Presisi adalah tingkat kesesuaian antara hasil analisis individual jika prosedur dilakukan berulang kali terhadap sampel yang homogen. Konsentrasi terpilih untuk larutan 9tC18:1 adalah $0,1000 \mathrm{mg} / \mathrm{mL}$ karena merepresentasikan konsentrasi 9t-C18:1 pada sampel spike untuk uji akurasi, sementara untuk larutan baku C18:2 adalah $0,0250 \mathrm{mg} / \mathrm{mL}$ karena merepresentasikan nilai tengah dari lima konsentrasi dari tahap uji linieritas. Larutan terpilih dianalisis dengan KG sebanyak enam kali. Presisi metode analisis dinyatakan sebagai simpangan baku relatif (relative standard deviation, $R S D$ ), di mana metode dikatakan menghasilkan data yang presisi apabila data pengukuran pada minimal 6 sampel dengan konsentrasi sama yang dilakukan oleh satu orang memiliki $R S D$ kurang dari atau sama dengan 2/3 $R S D$ Horwitz $(R S D H) \quad(\mathrm{ICH}, 2005)$. Nilai $R S D H$ diperoleh dengan rumus sebagai berikut:

$$
R S D H=2^{(1-0,5 \log \mathrm{C})}
$$

di mana $\mathrm{C}$ adalah fraksi konsentrasi dari analit yang terukur dalam sampel.

\section{Tahap orientasi prosedur uji}

Tahap orientasi prosedur uji bertujuan untuk mempersiapkan larutan uji yang akan digunakan pada tahap validasi. Tahap ini meliputi dua tahap utama, yaitu ekstraksi lemak dan derivatisasi asam lemak.

Tahap ekstraksi lemak bertujuan untuk memisahkan komponen lemak dari matriks produk pangan. Proses ekstraksi diawali dengan pencampuran $3 \mathrm{~g}$ sampel donat yang telah dihancurkan dengan $20 \mathrm{~mL}$ campuran kloroform (Merck, Germany) dan metanol (Merck, Germany) dengan perbandingan 2:1. Campuran dihomogenisasi menggunakan stirrer selama 1 jam kemudian disaring dengan kertas saring. Suspensi hasil penyaringan diambil kemudian ditambahkan $4 \mathrm{~mL} \mathrm{NaCl}$ (Merck, Germany) $0,88 \%$ dan divorteks. Setelah terbentuk dua lapisan, lapisan atas dibuang sementara lapisan bawah disaring dengan kertas saring yang di atasnya diberi $\mathrm{Na}_{2} \mathrm{SO}_{4}$ anhidrat (Merck, Germany). Hasil penyaringan dipekatkan dengan gas $\mathrm{N}_{2}$ teknis (CV. Krakatau Raya, Indonesia) hingga mencapai berat konstan. Massa yang tersisa setelah penghembusan dengan gas $\mathrm{N}_{2}$ adalah ekstrak lemak dari sampel yang kemudian disimpan dalam botol gelap di refrigerator.

Tahap derivatisasi bertujuan untuk mengubah asam lemak hasil hidrolisis menjadi FAME yang mudah menguap agar dapat dianalisis dengan instrumen KG. Tahap ini diawali dengan penimbangan ekstrak lemak sebanyak 100,00 mg dalam tabung reaksi bertutup, yang dilanjutkan dengan penambahan $1 \mathrm{~mL}$ larutan baku internal (C17:0) dengan konsentrasi $1,0 \mathrm{mg} / \mathrm{mL}$ dalam heksana (Merck, Germany). Larutan dihomogenisasi dengan vorteks kemudian ditambahkan $2 \mathrm{~mL} \mathrm{NaOH}$ (Merck, Germany) metanolik 0,5 N. Penambahan $\mathrm{NaOH}-$ metanolik bertujuan menghidrolisis lemak menjadi asam lemak. Larutan dihomogenisasi kembali lalu dihembus dengan gas $\mathrm{N}_{2}$ selama 60 detik. Tabung yang telah dihembus ditutup rapat, dan dipanaskan pada suhu $80^{\circ} \mathrm{C}$ selama 5 menit. Setelah dipanaskan, tabung didinginkan pada suhu ruang, kemudian dilakukan penambahan $2 \mathrm{~mL} \mathrm{BF}_{3}$-metanol yang terdiri atas 20\% $\mathrm{BF}_{3}$ (Merck, Germany) dalam metanol (Merck, Germany). Tahapan ini dilanjutkan dengan proses homogenisasi dan penghembusan gas $\mathrm{N}_{2}$. Tabung dipanaskan pada suhu $80^{\circ} \mathrm{C}$ selama 30 menit. Setelah itu tabung didinginkan di bawah air mengalir hingga mencapai suhu ruang. Kemudian ke dalam larutan ditambahkan 1,5 $\mathrm{mL}$ heksana dan $3 \mathrm{~mL} \mathrm{NaCl}$ jenuh. Larutan dihomogenisasi dengan vorteks, kemudian didiamkan hingga 
terbentuk dua lapisan. Lapisan atas, yang merupakan $F A M E$, dipipet dan dimasukkan ke dalam vial amber berisi $\mathrm{Na}_{2} \mathrm{SO}_{4}$ anhidrat, kemudian disimpan dalam freezer. Tahap derivatisasi ini dilakukan sebanyak enam ulangan, di mana larutan uji yang dihasilkan kemudian dianalisis dengan $K G$ pada tahap validasi metode.

\section{Tahap validasi metode}

Tahap validasi metode bertujuan untuk mengukur performa data hasil analisis dengan metode AOCS Official Method Ce1h-05 termodifikasi untuk senyawa 9t-C18:1 pada matriks donat yang telah diekstraksi dan diderivatisasi. Parameter yang diukur adalah presisi, akurasi, dan spesifisitas.

\section{Presisi}

Validasi presisi dilakukan dengan melakukan analisis KG sesuai prosedur AOCS Official Method Ce1h-05 termodifikasi terhadap enam larutan uji dari tahap orientasi prosedur uji secara duplo. Sebanyak $1 \mu \mathrm{L}$ FAME diinjeksikan ke dalam KG dengan menggunakan SGE microliter syringe (Sigma Aldrich, USA) kapasitas $10 \mu \mathrm{L}$. Kromatogram hasil analisis memiliki waktu retensi sebagai sumbu $x$ dan intensitas sebagai sumbu $y$. Kuantifikasi asam lemak dilakukan dengan menggunakan rumus perhitungan Alx seperti tercantum di bagian Tahap Persiapan. Hasil analisis dikatakan presisi jika nilai $R S D$ sampel kurang dari atau sama dengan 2/3 $R S D H$.

\section{Akurasi}

Akurasi menunjukkan derajat kedekatan hasil analisis dengan kadar analit sebenarnya. Validasi akurasi dilakukan dengan metode penambahan baku atau menggunakan sampel spike. Metode ini dieksekusi dengan menambahkan baku 9t-C18:1 konsentrasi $0,05 \mathrm{mg} / \mathrm{mL}$ ke dalam larutan uji pada tahap validasi presisi. Baku 9t-C18:1 konsentrasi $0,05 \mathrm{mg} / \mathrm{mL}$ dibuat dengan melarutkan $0,1 \mathrm{~mL}$ larutan 9t-C18-1 konsentrasi $25 \mathrm{mg} / \mathrm{mL}$ ke dalam 2,4 $\mathrm{mL}$ heksana, sehingga konsentrasinya menjadi 1 $\mathrm{mg} / \mathrm{mL}$. Kemudian larutan hasil pengenceran tersebut diambil sebanyak $25 \mu \mathrm{L}$ lalu dicampurkan dalam $475 \mu \mathrm{L}$ sampel, sehingga konsentrasinya menjadi $0,05 \mathrm{mg} / \mathrm{mL}$. Konsentrasi ini dipilih karena ketika ditambahkan dalam sampel, respon area yang dihasilkan tidak terlalu kecil sehingga tidak terdeteksi penambahannya, ataupun tidak terlalu besar sehingga menyebabkan area menyatu dengan C18:1 cis. Akurasi dinyatakan sebagai derajat perolehan kembali (rekoveri) baku yang ditambahkan ke dalam sampel. Persyaratan rekoveri berdasarkan AOAC (2012) pada konsentrasi $10 \mu \mathrm{g} / \mathrm{g}$ adalah $80-115 \%$.

\section{Spesifisitas}

Uji spesifisitas dilakukan untuk mengetahui kemampuan metode dalam merespon secara khusus analit tertentu tanpa terpengaruh oleh komponen lain dalam matriks. Validasi spesifisitas dilakukan dengan mengukur nilai resolusi (Rs) senyawa 9t-C18:1 pada baku eksternal serta membandingkan kromatogram larutan sampel dari tahap validasi presisi dengan kromatogram larutan sampel spike dari tahap validasi akurasi. Spesifisitas metode analisis dapat diterima jika nilai $\mathrm{Rs}$ lebih dari 1,0 , puncak setiap asam lemak pada kromatogram terpisah dengan baik dan penambahan analit berupa baku 9t-C18:1 menimbulkan respon signifikan pada kromatogram.

\section{HASIL DAN PEMBAHASAN}

\section{Unjuk kerja instrumen}

Pengecekan unjuk kerja instrumen diawali dengan analisis KG untuk larutan baku eksternal yang terdiri dari larutan baku FAME campuran (C8C22, 19 asam lemak) dan larutan baku FAME campuran isomer C18:2 (9t,12t-C18:2 (50\%); 9c,12tC18:2 (20\%); 9t,12c-C18:2 (20\%); dan C18:2 cis $(10 \%)$. Analisis ini dilakukan untuk mengetahui waktu retensi dan $R F$ setiap asam lemak yang ada dalam larutan, yang selanjutnya dapat digunakan sebagai acuan identifikasi dan kuantifikasi asam lemak dalam sampel. Kromatogram hasil analisis baku eksternal dapat dilihat pada Gambar 1. Data analisis $R F$ dapat dilihat pada Tabel 4. Nilai $R F$ seharusnya berada pada kisaran 0,90 sampai 1,00 , namun terjadi penyimpangan pada senyawa C18:3 dan C20:0 yang masing-masing memberikan respon luas area tidak normal sehingga memiliki nilai $R F$ 4,0117 dan 0,4427. Penyimpangan ini terjadi akibat ko-elusi FAME C18:3 dan C20:1 pada kolom SP2340 setelah 114 kali injeksi yang ternyata juga mengakibatkan penyimpangan pada C20:0. Nilai ini menyebabkan data menyimpang jika dimasukkan dalam kuantifikasi profil asam lemak untuk C18:3, C20:0, dan C20:1. 


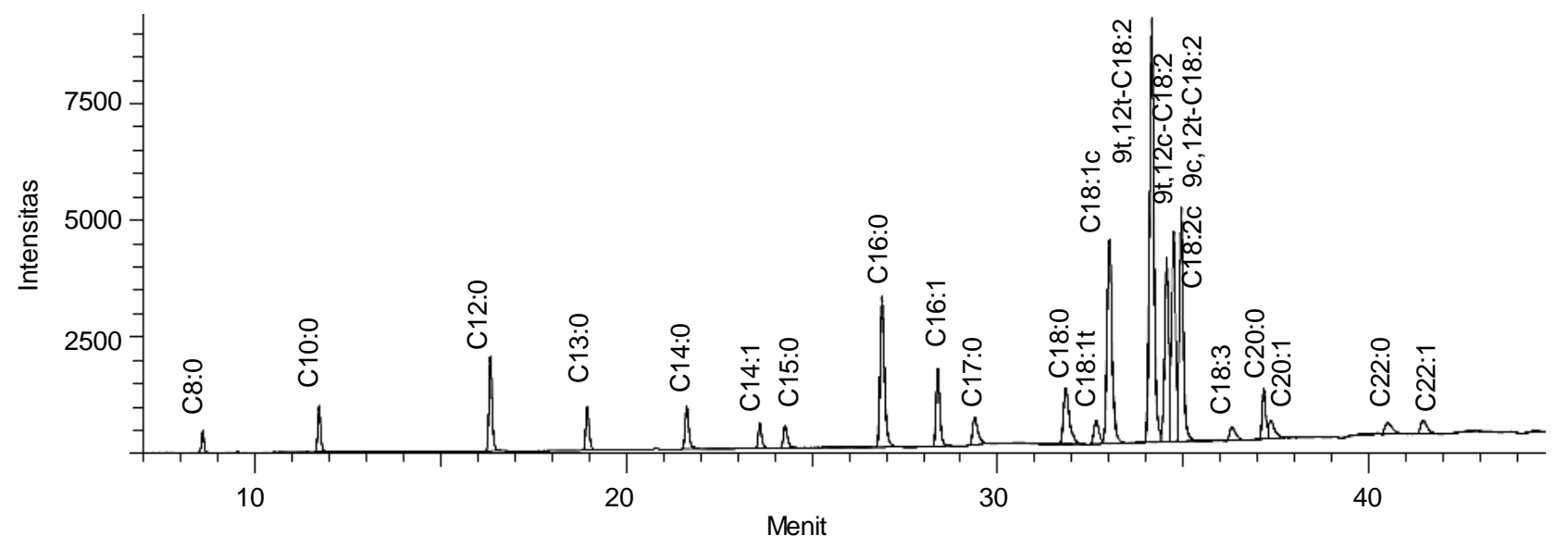

Gambar 1. Kromatogram baku eksternal

Tabel 4. Analisis nilai RF

\begin{tabular}{lccccc}
\hline Asam Lemak & Luas Area SI & $\begin{array}{c}\text { Luas Area Asam } \\
\text { Lemak }\end{array}$ & $\begin{array}{c}\text { Bobot Asam } \\
\text { Lemak }(\mathrm{mg})\end{array}$ & Bobot SI $(\mathrm{mg})$ & $R F$ \\
\hline C8:0 & 63877 & 23437 & 0,0951 & 0,1600 & 1,6200 \\
C10:0 & 63877 & 58848 & 0,1596 & 0,1600 & 1,0827 \\
C12:0 & 63877 & 134413 & 0,3277 & 0,1600 & 0,9733 \\
C13:0 & 63877 & 67374 & 0,1598 & 0,1600 & 0,9466 \\
C14:0 & 63877 & 68839 & 0,1597 & 0,1600 & 0,9262 \\
C14:1 & 63877 & 38166 & 0,0948 & 0,1600 & 0,9916 \\
C15:0 & 63877 & 38609 & 0,0948 & 0,1600 & 0,9803 \\
C16:0 & 63877 & 290431 & 0,6489 & 0,1600 & 0,8920 \\
C16:1 & 63877 & 143111 & 0,3196 & 0,1600 & 0,8914 \\
C17:0 & 63877 & 63877 & 0,1600 & 0,1600 & 1,0000 \\
C18:0 & 63877 & 138420 & 0,3243 & 0,1600 & 0,9353 \\
9t-C18:1 & 63877 & 41560 & 0,1298 & 0,1600 & 1,2469 \\
C18:1 cis & 63877 & 471457 & 0,9780 & 0,1600 & 0,8282 \\
9t,12t-C18:2 & 63877 & 342339 & 0,6250 & 0,1600 & 0,7289 \\
9t,12c-C18:2 & 63877 & 121510 & 0,2500 & 0,1600 & 0,8214 \\
9c,12t-C18:2 & 63877 & 127217 & 0,2500 & 0,1600 & 0,7845 \\
C18:2 cis & 63877 & 435240 & 0,7739 & 0,1600 & 0,7099 \\
C18:3 & 63877 & 31766 & 0,3192 & 0,1600 & 4,0117 \\
C20:0 & 63877 & 85497 & 0,0948 & 0,1600 & 0,4427 \\
C20:1 & 63877 & 42261 & 0,0951 & 0,1600 & 0,8984 \\
C22:0 & 63877 & 41379 & 0,0952 & 0,1600 & 0,9180 \\
C22:1 & 63877 & 38133 & 0,0948 & 0,1600 & 0,9925 \\
\hline
\end{tabular}

Fenomena ini sesuai dengan peringatan yang tertulis pada AOAC (2000) terkait penggunaan kolom SP-2340. Karena keterbatasannya, metode ini tidak diperuntukkan bagi sampel yang mengandung C18:3, C20:0, dan C20:1. Pada tahap ini juga dilakukan evaluasi untuk menentukan linieritas, rentang kerja, batas deteksi dan kuantitasi, serta presisi. Senyawa yang dianalisis adalah larutan baku FAME 9t-C18:1 dan FAME campuran isomer C18:2. Hasil uji linieritas larutan baku 9t-C18:1 dan FAME campuran isomer C18:2 beserta rentang konsentrasi ujinya dapat dilihat pada Tabel 5. Kurva linieritas larutan baku 9t-C18:1 dapat dilihat pada Gambar 2. Data simpangan baku dan kemiringan kurva dari uji linieritas digunakan untuk menganalisis $L O D$ dan $L O Q$ masing-masing senyawa yang secara rinci dapat dilihat pada Tabel 6. Pada Tabel 6 juga ditampilkan nilai rentang kerja untuk 9t-C18:1, yaitu sebesar 0,0020 sampai $0,1200 \mathrm{mg} / \mathrm{mL}$.

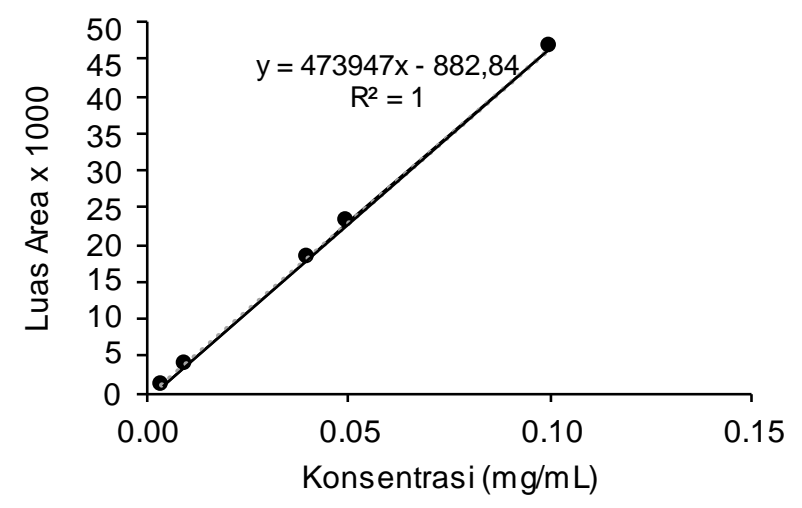

Gambar 2. Kurva linieritas baku 9t-C18:1 
Parameter presisi juga diuji pada tahap pengecekan unjuk kerja instrumen, di mana larutan baku 9t-C18:1 0,1000 $\mathrm{mg} / \mathrm{mL}$ dan larutan baku C18:2 0,0250 $\mathrm{mg} / \mathrm{mL}$ dari tahap validasi linieritas instrumen dianalisis dengan KG sebanyak enam kali. Data hasil analisis menunjukkan bahwa semua data memiliki $R S D$ kurang dari $2 / 3 R S D H$, sehingga metode modifikasi dinyatakan mampu menghasilkan data yang presisi. Data hasil analisis presisi dapat dilihat pada Tabel 7.

Tabel 5. Hasil uji linieritas

\begin{tabular}{|c|c|c|c|}
\hline Senyawa & $\begin{array}{c}\text { Konsentrasi } \\
(\mathrm{mg} / \mathrm{mL})\end{array}$ & $\begin{array}{c}\text { Persamaan } \\
\text { Kurva }\end{array}$ & $\mathrm{R}^{2}$ \\
\hline $9 t-C 18: 1$ & $0,0040-0,1000$ & $\begin{array}{c}y=473947 x- \\
882,4\end{array}$ & 1 \\
\hline $\begin{array}{l}\text { 9t,12t- } \\
\text { C18:2 }\end{array}$ & $0,00125-0,3750$ & $\begin{aligned} & y= 889122 x+ \\
& 4237,7\end{aligned}$ & 0,9999 \\
\hline $\begin{array}{l}\text { 9t,12c- } \\
\text { C18:2 }\end{array}$ & $0,0005-0,1500$ & $\begin{array}{c}y=915416 x+ \\
2043,1\end{array}$ & 0,9999 \\
\hline $\begin{array}{l}\text { 9c,12t- } \\
\text { C18:2 }\end{array}$ & $0,0005-0,1500$ & $\begin{aligned} y= & 949792 x+ \\
& 2158,8\end{aligned}$ & 0,9999 \\
\hline $\begin{array}{l}\text { C18:2 } \\
\text { cis }\end{array}$ & $0,00025-0,0750$ & $\begin{array}{c}y=782406 x+ \\
760,66\end{array}$ & 0,9999 \\
\hline
\end{tabular}

\section{Orientasi prosedur uji}

Orientasi prosedur uji merupakan tahap pembuatan larutan uji yang terdiri dari tahap ekstraksi lemak dan derivatisasi asam lemak. Donat merupakan produk yang berpotensi mengandung asam lemak trans karena diolah menggunakan bahanbahan hasil hidrogenasi parsial, seperti margarin dan shortening. Ekstraksi lemak metode Folch dilakukan pada 10,0494 $\mathrm{g}$ donat dan menghasilkan 2,0071 g lemak, sehingga diperoleh kadar lemak donat sebesar 19,97\%. Ekstrak lemak donat kemudian dihidrolisis dan diderivatisasi, lalu diencerkan sebanyak 20 kali untuk dijadikan larutan uji pada tahap validasi presisi dan akurasi metode. Pembuatan larutan uji ini dilakukan sebanyak enam ulangan dengan metode AOCS Official Method Ce 2-66 termodifikasi. Kromatogram asam lemak dalam sampel donat dapat dilihat pada Gambar 3.

\section{Presisi}

Data hasil validasi presisi dapat dilihat pada Tabel 8. Semua data memenuhi persyaratan presisi dengan $R S D$ kurang dari 2/3 $R S D H$, baik untuk kadar asam lemak (mg/g lemak) maupun persen asam lemak terhadap asam lemak total, kecuali untuk senyawa C14:0. Hal ini disebabkan oleh kadar C14:0 yang terlalu rendah dalam sampel sehingga perubahan baseline sedikit saja dapat berpengaruh besar pada luas area. Berdasarkan data yang diperoleh, asam lemak dominan yang terkandung dalam donat adalah C16:0 dengan kadar 180,66 $\pm 2,42 \mathrm{mg} / \mathrm{g}$ lemak atau $39,50 \pm 0,35 \%$ dari total asam lemak, dan C18:1 dengan kadar 180,03 $\pm 3,08 \mathrm{mg} / \mathrm{g}$ lemak atau $39,36 \pm 0,26 \%$ dari total asam lemak. Donat juga mengandung asam lemak 9t-C18:1 sebanyak 33,03 $\pm 0,59 \mathrm{mg} / \mathrm{g}$ lemak atau 7,22 $\pm 0,05 \%$ dari total asam lemak. Dengan takaran saji $40 \mathrm{~g}$ serta kandungan lemak sebesar 19,97\%, kandungan asam lemak 9t-C18:1 dalam donat dapat dinyatakan sebagai 0,26 g/takaran saji. Karena mengandung kurang dari 0,5 g ALT/takaran saji, sesuai aturan FDA, donat ini dikategorikan bukan sebagai sumber ALT.

Tabel 6. Hasil analisis $L O D$ dan $L O Q$

\begin{tabular}{lccccc}
\multicolumn{1}{c}{ Senyawa } & $\begin{array}{c}\text { Simpangan Baku } \\
(\sigma)\end{array}$ & $\begin{array}{c}\text { Kemiringan Kurva } \\
(\mathrm{S})\end{array}$ & $\begin{array}{c}\text { LoD } \\
(\mathrm{mg} / \mathrm{mL})\end{array}$ & $\begin{array}{c}\text { LoQ } \\
(\mathrm{mg} / \mathrm{mL})\end{array}$ & $\begin{array}{c}\text { Rentang Kerja } \\
(\mathrm{mg} / \mathrm{mL})\end{array}$ \\
\hline 9t-C18:1 & 94,8611 & 473947,0540 & 0,0007 & 0,0020 & $0,0020-0,1200$ \\
9t,12t-C18:2 & 889,3804 & 889122,1858 & 0,0033 & 0,0100 & \\
9t,12c-C18:2 & 410,6763 & 915416,2449 & 0,0015 & 0,0045 \\
9c,12t-C18:2 & 421,1015 & 949792,2860 & 0,0015 & 0,0044 \\
C18:2 cis & 150,3350 & 782406,2539 & 0,0006 & 0,0019 & \\
\hline
\end{tabular}

Tabel 7. Kuantifikasi data presisi baku 9t-C18:1 dan C18:2

\begin{tabular}{|c|c|c|c|c|c|}
\hline \multirow[t]{2}{*}{ Ulangan } & $\begin{array}{c}9 \mathrm{t}-\mathrm{C} 18: 1 \\
0,1000 \mathrm{mg} / \mathrm{mL}\end{array}$ & $\begin{array}{c}9 t, 12 t-C 18: 2 \\
0,0125 \mathrm{mg} / \mathrm{mL}\end{array}$ & $\begin{array}{c}9 \mathrm{t}, 12 \mathrm{c}-\mathrm{C} 18: 2 \\
0,0050 \mathrm{mg} / \mathrm{mL}\end{array}$ & $\begin{array}{c}9 \mathrm{c}, 12 \mathrm{t}-\mathrm{C} 18: 2 \\
0,0050 \mathrm{mg} / \mathrm{mL}\end{array}$ & $\begin{array}{c}\text { C18:2 cis } \\
0,00125 \mathrm{mg} / \mathrm{mL}\end{array}$ \\
\hline & Luas Area & Luas Area & Luas Area & Luas Area & Luas Area \\
\hline 1 & 48595 & 21962 & 9845 & 10326 & 4088 \\
\hline 2 & 48805 & 21534 & 9506 & 9983 & 3848 \\
\hline 3 & 48863 & 21647 & 9509 & 10157 & 3956 \\
\hline 4 & 48604 & 21964 & 9618 & 10078 & 3985 \\
\hline 5 & 48838 & 22306 & 9922 & 10673 & 4203 \\
\hline 6 & 48721 & 21544 & 9536 & 10168 & 3867 \\
\hline Rata-rata & 48737,67 & 21826,17 & 9656,00 & 10230,80 & 3991,17 \\
\hline$S D$ & 117,31 & 304,88 & 182,44 & 244,44 & 135,23 \\
\hline$R S D$ & 0,24 & 1,40 & 1,89 & 2,39 & 3,39 \\
\hline
\end{tabular}




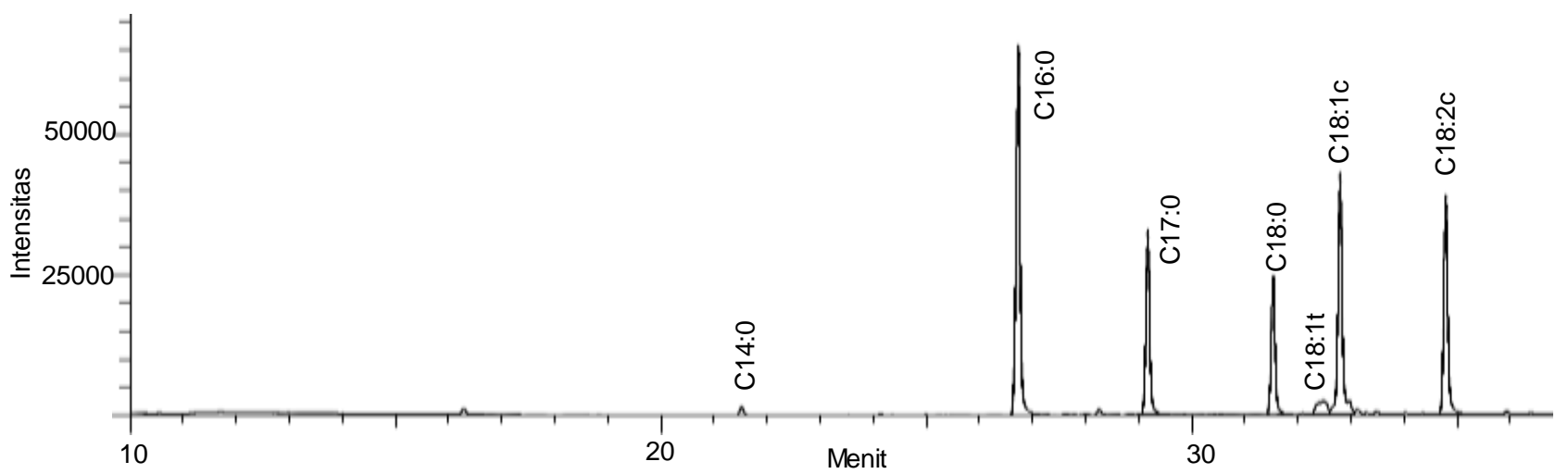

Gambar 3. Kromatogram asam lemak dalam sampel donat

Tabel 8. Data validasi presisi

\begin{tabular}{lcccccccc}
\hline Asam Lemak & $\mathrm{mg} / \mathrm{g} \mathrm{Lemak}$ & $S D$ & $R S D(\%)$ & $2 / 3 R S D H$ & $\% \mathrm{AL}$ & $S D$ & $R S D(\%)$ & $2 / 3 R S D H$ \\
\hline C14:0 & 4,09 & 0,26 & 6,40 & 3,05 & 0,89 & 0,05 & 5,89 & 2,71 \\
C16:0 & 180,66 & 2,42 & 1,34 & 1,73 & 39,50 & 0,35 & 0,89 & 1,53 \\
C18:0 & 33,92 & 0,57 & 1,68 & 2,22 & 7,42 & 0,07 & 0,89 & 1,97 \\
Total SFA & 218,67 & 2,92 & 1,34 & 1,68 & 47,82 & 0,34 & 0,72 & 1,49 \\
9t-C18:1 & 33,03 & 0,59 & 1,78 & 2,23 & 7,22 & 0,05 & 0,72 & 1,98 \\
C18:1 cis & 180,03 & 3,08 & 1,71 & 1,73 & 39,36 & 0,26 & 0,66 & 1,53 \\
Total MUFA & 213,06 & 3,58 & 1,68 & 1,68 & 46,59 & 0,26 & 0,56 & 1,50 \\
C18:2 cis & 25,60 & 0,57 & 2,24 & 2,31 & 5,60 & 0,10 & 1,80 & 2,06 \\
Total PUFA & 25,60 & 0,57 & 2,24 & 2,31 & 5,60 & 0,10 & 1,80 & 2,06 \\
Total area & 457,33 & 6,27 & 1,37 & 1,50 & 100,00 & 0,00 & 0,00 & 1,33 \\
\hline
\end{tabular}

Keterangan: ${ }^{a} S F A=$ Saturated Fatty Acid (Asam Lemk Jenuh), MUFA= Monounsaturated Fatty Acid (Asam Lemak Tidak Jenuh Tunggal), PUFA= Polyunsaturated Fatty Acid (Asam Lemak Tidak Jenuh Jamak), \%AL = \% asam lemak dari total asam lemak

\section{Akurasi}

Metode yang digunakan untuk uji akurasi adalah metode penambahan baku atau menggunakan sampel spike. Sampel spike merupakan sampel dari tahap validasi presisi ditambahkan dengan baku 9t-C18:1 0,05 mg/mL. Kadar 9t-C18:1 pada sampel spike dibandingkan dengan kadar 9t-C18:1 pada sampel murni, di mana nilai akurasi dapat dinyatakan sebagai persen rekoveri kadar baku 9t-C18:1. Pada proses validasi akurasi, sebelum analisis rekoveri, perlu dilakukan penyetaraan data antara sampel dan sampel spike. Penyetaraan ini dilakukan dengan menghitung luas area sampel bila luas area baku internalnya sama dengan luas baku internal pada sampel spike. Data hasil penyetaraan dapat dilihat pada Tabel 9. Setelah dilakukan penyetaraan, persen rekoveri dapat dihitung dengan membandingkan konsentrasi baku terukur dari kurva linieritas dengan konsentrasi baku yang ditambahkan. Hasil analisis rekoveri (Tabel 10) menunjukkan bahwa dari enam ulangan larutan uji yang dianalisis secara duplo diperoleh data rekoveri dengan rata-rata 85,98 $\pm 5,41 \%$ pada rentang $80,54-94,25 \%$. Hasil ini memenuhi persyaratan rekoveri pada konsentrasi 10 $\mu \mathrm{g} / \mathrm{g}$ yaitu $80-115 \%$ (AOAC, 2012).

\section{Spesifisitas}

Uji spesifisitas dilakukan untuk mengetahui kemampuan metode dalam merespon secara khusus analit tertentu tanpa terpengaruh oleh komponen lain dalam matriks. Spesifisitas yang baik dari metode dapat dilihat dari nilai resolusi asam lemak 9t-C18:1 pada baku eksternal sebesar 1,2, puncakpuncak analit yang terpisah pada kromatogram, serta respon peningkatan luas area puncak 9t-C18:1 setelah penambahan baku $0,05 \mathrm{mg} / \mathrm{mL}$. Perbandingan kromatogram sampel dan sampel spike dapat dilihat pada Gambar 4 dan Gambar 5. Hasil validasi keseluruhan pada senyawa target 9t-C18:1 ditampilkan pada Tabel 11.

\section{Keunggulan, keterbatasan dan aplikasi metode} Metode modifikasi dari AOCS Ce 1h-05 memiliki keunggulan dibandingkan dengan metode AOCS Ce 1h-05 standar. Disebutkan dalam dokumen AOCS Ce 1h-05 bahwa penggunaan suhu isotermal dan kolom SP-2560 atau CP-Sil 88 dapat menyebabkan ko-elusi pada senyawa C18:1, C18:3, dan C20:1 (AOCS, 2005). Ko-elusi pada isomerisomer $\mathrm{C} 18: 1$ sangat tidak diharapkan, karena selain menjadi senyawa target dalam validasi metode ini, 9t-C18:1 merupakan ALT yang paling banyak terakumulasi dalam produk pangan. Fenomena koelusi pada senyawa C18:1 dapat dihindari dengan penggunaan metode modifikasi yang menggunakan kolom SP-2340 dengan pengaturan suhu kolom terprogram. 
Tabel 9. Penyetaraan luas area antara sampel dan sampel spike

\begin{tabular}{|c|c|c|c|c|c|c|c|}
\hline \multirow[b]{2}{*}{ Ulangan } & \multicolumn{4}{|c|}{ Sampel } & \multicolumn{2}{|c|}{ Sampel Spike } & \multirow{2}{*}{$\begin{array}{l}\text { Sampel (Konversi) } \\
\text { L. Area 9t-C18:1 }\end{array}$} \\
\hline & L. Area SI & $\begin{array}{c}\text { L. Area } \\
\text { 9t-C18:1 }\end{array}$ & $\begin{array}{l}\text { Rasio L. Area } \\
9 \mathrm{t}-\mathrm{C} 18: 1: \mathrm{SI}\end{array}$ & Rata-rata Rasio & L. Area SI & $\begin{array}{l}\text { L. Area } \\
\text { 9t-C18:1 }\end{array}$ & \\
\hline \multirow[t]{2}{*}{1} & 11717 & 33515 & 2,8604 & 2,8817 & 10815 & 49480 & 31166 \\
\hline & 11689 & 33934 & 2,9031 & & 10940 & 50266 & 31526 \\
\hline \multirow[t]{2}{*}{2} & 13707 & 35373 & 2,5807 & 2,5843 & 11044 & 47151 & 28541 \\
\hline & 13109 & 33925 & 2,5879 & & 11985 & 49602 & 30973 \\
\hline \multirow[t]{2}{*}{3} & 12140 & 33859 & 2,7890 & 2,8250 & 11356 & 52046 & 32081 \\
\hline & 11638 & 33296 & 2,8610 & & 10824 & 48780 & 30578 \\
\hline \multirow[t]{2}{*}{4} & 14627 & 41629 & 2,8460 & 2,8039 & 14208 & 58131 & 39837 \\
\hline & 14134 & 39034 & 2,7617 & & 14321 & 58946 & 40154 \\
\hline \multirow[t]{2}{*}{5} & 15693 & 41379 & 2,6368 & 2,6090 & 14548 & 58418 & 37956 \\
\hline & 15533 & 40095 & 2,5813 & & 14625 & 59610 & 38157 \\
\hline \multirow[t]{2}{*}{6} & 14911 & 41140 & 2,7590 & 2,7296 & 14050 & 59385 & 38350 \\
\hline & 14568 & 39335 & 2,7001 & & 13469 & 58161 & 36765 \\
\hline
\end{tabular}

Keterangan: 'Luas area sampel konversi digunakan untuk analisis rekoveri di mana data sampel konversi menjadi luas area $9 \mathrm{t}-\mathrm{C} 18: 1$

Tabel 10. Analisis rekoveri

\begin{tabular}{|c|c|c|c|c|c|}
\hline Sampel & $\begin{array}{c}\text { L.area 9t-C18:1 } \\
\text { pada Sampel } \\
\text { Murni }\end{array}$ & $\begin{array}{l}\text { L. area } 9 \mathrm{t}-\mathrm{C} 18: 1 \\
\text { pada Sampel } \\
\text { Spike }\end{array}$ & Selisih L.Area & $\begin{array}{l}\text { Konsentrasi baku } \\
\text { 9t-C18:1 terukur } \\
(\mathrm{mg} / \mathrm{mL})\end{array}$ & Rekoveri (\%) \\
\hline \multirow[t]{2}{*}{1} & 31166 & 49480 & 18314 & 0,0405 & 81,01 \\
\hline & 31526 & 50266 & 18740 & 0,0414 & 82,81 \\
\hline \multirow[t]{2}{*}{2} & 28541 & 47151 & 18610 & 0,0411 & 82,26 \\
\hline & 30973 & 49602 & 18629 & 0,0412 & 82,34 \\
\hline \multirow[t]{2}{*}{3} & 32081 & 52046 & 19965 & 0,0440 & 87,98 \\
\hline & 30578 & 48780 & 18202 & 0,0403 & 80,54 \\
\hline \multirow[t]{2}{*}{4} & 39837 & 58131 & 18294 & 0,0405 & 80,92 \\
\hline & 40154 & 58946 & 18792 & 0,0415 & 83,02 \\
\hline \multirow[t]{2}{*}{5} & 37956 & 58418 & 20462 & 0,0450 & 90,07 \\
\hline & 38157 & 59610 & 21453 & 0,0471 & 94,25 \\
\hline \multirow[t]{5}{*}{6} & 38350 & 59385 & 21035 & 0,0462 & 92,49 \\
\hline & 36765 & 58161 & 21396 & 0,0470 & 94,02 \\
\hline & & & & Rata-rata & 85,98 \\
\hline & & & & $S D$ & 5,41 \\
\hline & & & & Rentang & $80,54-94,25$ \\
\hline
\end{tabular}

Tabel 11. Hasil validasi metode pada senyawa 9t-C18:1

\begin{tabular}{|c|c|c|c|c|c|}
\hline Parameter & Data/Rerata & $S D$ & $R S D(\%)$ & $2 / 3 R S D H$ & Persyaratan \\
\hline Linieritas & $R^{2}=1$ & & & & $\mathrm{R}^{2}>0,990(\mathrm{AOAC}, 2012)$ \\
\hline Rentang kerja ( $\mathrm{mg} / \mathrm{mL})$ & $0,0020-0,1200$ & & & & \\
\hline Presisi $(\mathrm{mg} / \mathrm{g})$ & 33,03 & 0,59 & 1,78 & 2,23 & $\begin{array}{l}R S D<2 / 3 R S D H \\
(I C H, 2005)\end{array}$ \\
\hline Presisi (\%AL) & 7,22 & 0,05 & 0,72 & 1,98 & $\begin{array}{l}R S D<2 / 3 R S D H \\
(\mathrm{ICH}, 2005)\end{array}$ \\
\hline Rekoveri (\%) & $80,54-94,25$ & 5,41 & 6,29 & & $\begin{array}{l}10 \mu \mathrm{g} / \mathrm{g}, 80-115 \% \\
(\mathrm{AOAC}, 2012)\end{array}$ \\
\hline $\begin{array}{l}\text { Spesifisitas } \\
L o D(\mathrm{mg} / \mathrm{mL})\end{array}$ & $\begin{array}{c}\mathrm{Rs}=1,2 \\
0,0007\end{array}$ & & & & \\
\hline
\end{tabular}

Metode modifikasi juga memiliki keterbatasan yang terkait dengan peristiwa koelusi. Setelah 114 kali injeksi, ditemukan bahwa terjadi ko-elusi senyawa C18:3, C20:0, dan C20:1 yang ditandai dengan penyimpangan nilai RF pada kuantitasi baku eksternal (Tabel 5). Temuan ini menjadi pembatas penggunaan metode, di mana penggunaan metode ini tidak dianjurkan untuk sampel yang mengandung C18:3, C20:0, dan C20:1. Meskipun demikian, bila dibandingkan dengan metode standar, metode modifikasi ini dinilai lebih implementatif untuk identifikasi profil ALT, karena tidak dibatasi untuk sampel yang mengandung 9t-C18:1 sebagai produk ALT utama pada produk pangan.

Mengingat karakteristik kolom SP-2340 yang rentan terhadap kontaminasi, perawatan kolom menjadi faktor penting dalam mempertahankan performa data analisis dan memperpanjang umur 
kolom. Berdasarkan pengalaman selama penelitian, disusunlah beberapa poin prosedur operasi standar untuk memaksimalkan umur dan performa kolom: 1) Kolom harus melalui tahap pemanasan atau conditioning setiap hari, satu jam di awal sebelum injeksi sampel pertama dan satu jam di akhir sesudah injeksi sampel terakhir; 2). Sebaiknya dalam satu hari tidak diinjeksi lebih dari 6 sampel. Jika harus lebih daripada jumlah tersebut, setiap injeksi 2 sampel, proses diselingi dengan injeksi heksana yang bertujuan memberi jeda waktu antar sampel sehingga kolom tidak jenuh; 3 ) Kolom harus dipanaskan selama 12-24 jam satu kali seminggu. Hal ini dilakukan untuk membersihkan sekaligus meregenerasi kolom secara periodik, sehingga laju penurunan performa kolom dapat dihambat; 4) Untuk meminimalkan kontaminasi sampel pada injektor, dilakukan penggantian septum setiap injeksi 30 sampel; 5) Untuk menjamin bahwa kuantifikasi data dari kromatogram sesuai dengan kondisi terkini kolom, baku eksternal sebaiknya diinjeksi secara periodik setiap 10 sampel.

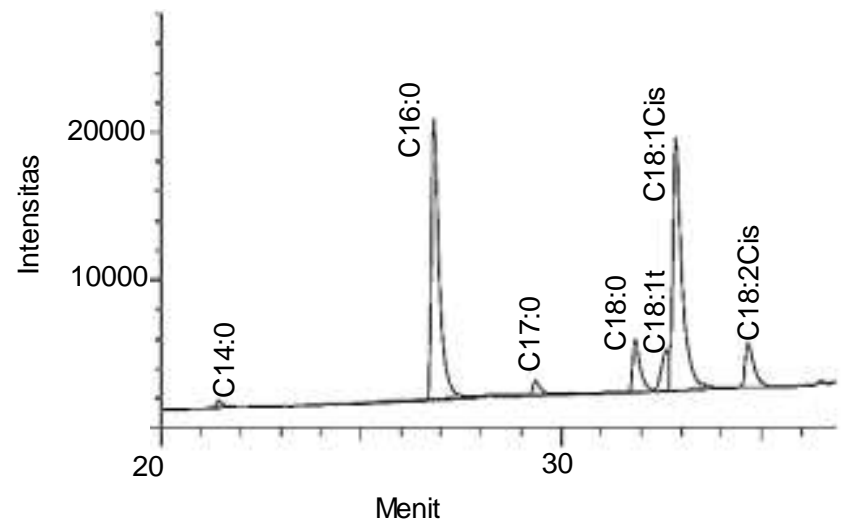

Gambar 4. Kromatogram asam lemak dalam sampel donat

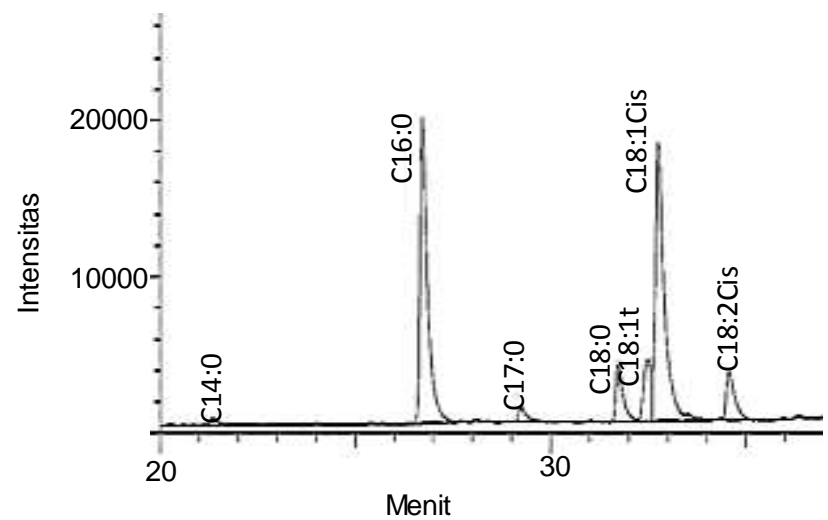

Gambar 5. Ko-kromatogram asam lemak dalam sampel donat dengan penambahan baku 9t-C18:1 $0,05 \mathrm{mg} / \mathrm{mL}$

\section{KESIMPULAN}

Hasil validasi menunjukkan bahwa metode Folch dapat digunakan untuk ekstraksi lemak, AOCS Official Method Ce 2-66 termodifikasi dapat digunakan untuk derivatisasi asam lemak, serta AOCS Official Method Ce 1h-05 termodifikasi dapat digunakan untuk analisis KG di laboratorium SEAFAST untuk menganalisis profil asam lemak, termasuk komponen asam lemak trans pada bahan pangan. Hasil validasi instrumen telah memenuhi kriteria linieritas dan presisi untuk senyawa 9t-C18:1 dan C18:2 (9t,12t-C18:2; 9t,12c-C18:2, 9c,12tC18:2, dan 9c,12c-C18:2) pada rentang kerja yang telah ditentukan. Validasi metode dilakukan untuk analisis senyawa 9t-C18:1 dalam $100 \mathrm{mg}$ ekstrak lemak donat. Hasil validasi menunjukkan bahwa metode modifikasi tervalidasi untuk parameter spesifisitas, presisi dan akurasi dengan data spesifisitas (Rs $=1,2$ ), presisi ( $R S D$ kadar asam lemak $1,78 \%$; RSD persen asam lemak terhadap asam lemak total $0,72 \%$ ) dan akurasi (persen rekoveri) $80,54-94,25 \%$. Hasil analisis profil asam lemak donat menunjukkan bahwa asam lemak dominan yang terkandung dalam donat adalah C16:0 dengan kadar 180,66 $\pm 2,42 \mathrm{mg} / \mathrm{g}$ lemak atau $39,50 \pm 0,35 \%$ dari total asam lemak, dan asam lemak C18:1 dengan kadar 180,03 $\pm 3,08 \mathrm{mg} / \mathrm{g}$ lemak atau $39,36 \pm 0,26 \%$ dari total asam lemak. Donat juga mengandung asam lemak 9t-C18:1 dengan kadar $33,03 \pm 0,59 \mathrm{mg} / \mathrm{g}$ lemak, $7,22 \pm 0,05 \%$ dari total asam lemak, atau $0,26 \mathrm{~g} /$ takaran saji.

\section{DAFTAR PUSTAKA}

[AOAC] Association of Official Agricultural Chemists. 2012. Official Methods of Analysis, Appendix K: Guidelines for Single Laboratory Validation of Chemical Methods for Dietary Supplements and Botanical. 19th edition, p.1-17. AOAC International, Gaithersburg, MD.

[AOAC] Association of Official Agricultural Chemists, Official Method. 2000. AOAC Official Method 996.06: Fat (Total, Saturated, and Unsaturated) in Foods. 18th Edition, p. 20-24. Official Methods of Analysis of AOAC International.

[AOCS] American Oil Chemist's Society, Official Method. 2005. AOCS official method Ce 1h-05: Determination of cis-, trans-, Saturated, Monounsaturated and Polyunsaturated fatty acids in Vegetable or Non-Ruminant Animal Oils and Fats by Capillary Gas-Liquid Chromatography. Sampling and Analysis of Commercial Fats and Oils, p. 1-29.

[AOCS] American Oil Chemist's Society, Official Method. 1997. AOCS official method Ce 2-66: Preparation of Methyl Esters of Fatty Acids. 
Sampling and Analysis of Commercial Fats and Oils, p. 1-2.

De Souza RJ, Mente A, Maroleanu A, Cozma Al, Ha $V$, Kishibe T, Uleryk E, Budylowski $P$, Schunemann H, Beyene J, Anand SS. 2015. Intake of saturated and trans unsaturated fatty acids and risk of all cause mortality, cardiovascular disease, and type 2 diabetes: Systematic review and meta-analysis of observational studies. BMJ (Online) 351: h3978: 1-16. DOI: 10.1136/bmj.h3978.

Delmonte P, Rader J. 2007. Evaluation of gas chromatographic methods for the determination of trans fat. Anal Bioanal Chem 389: 77-85. DOI: $10.1007 / \mathrm{s} 00216-007-1392-y$.

Folch J, Lees M, dan Sloane-Stanley GH. 1957. A simple method for the isolation and purification of total lipids from animal tissues. J Bio Chem 226: 497-509.

Gebauer SK, Destaillats F, Dionisi F, Krauss RM, Baer DJ. 2015. Vaccenic acid and trans fatty acid isomers from partially hydrogenated oil both adversely affect $L D L$ cholesterol: A double-blind, randomized controlled trial. Am J Clin Nutr 102: 1339-1346. DOI: 10.3945/ajcn. 115.116129.

Ganguly R, Pierce GN. 2015. The toxicity of dietary trans fats. Food Chem Toxicol 78: 170-176. DOI: 10.1016/j.fct.2015.02.004.

Hamilton M, Hopkins LE, AIZahal O, MacDonald TL, Cervone DT, Wright DC, McBride BW, Dyck DJ. 2015. Feeding butter with elevated content of trans-10, cis-12 conjugated linoleic acid to obese-prone rats impairs glucose and insulin tolerance. Lipids Health Dis 14: 119 DOI: 10.1186/s12944-015-0122-2.

Harvey KA, Arnold T, Rasool T, Antalis C, Miller SJ, Siddiqui RA. 2008. Trans-fatty acids induce pro -inflammatory responses and endothelial cell dysfunction. Br J Nutr 99: 723-731.

Hunter JE, Zhang J, Kris-Etherton PM. 2010. Cardiovascular disease risk of dietary stearic acid compared with trans, other saturated, and unsaturated fatty acids: A systematic review. Am J Clin Nutr 91: 46-63.

[ICH] International Conference on Harmonisation of Technical Requirements for Registration of Pharmaceuticals for Human Use. 2005. Validation of Analytical Procedures: Text and Methodology Q2(1).http://www.ich.org/fileadmin /Public_Web_Site/ICH_Products/Guidelines/Qu ality/Q2_R1/Step4/Q2_R1_Guideline.pdf [28 Januari 2015].

Kavanagh K, Jones KL, Sawyer J, Kelley K, Carr JJ, Wagner JD. 2007. Trans fat diet induces abdominal obesity and changes in insulin sensitivity in monkeys. Obesity (Silver Spring) 15: 1675-1684.

Magnusson, Ornemark U. 2014. Eurachem guide: The fitness for purpose of analytical methods-a laboratory guide to method validation and related topics, (2nd ed. 2014). ISBN 978-9187461-59-0. p.27-28. https://www.eurachem. org/images/stories/Guides/pdf/MV_guide_2nd_ ed_EN.pdf. [10 Januari 2015].

Merchant AT, Kelemen LE, de Koning L, Lonn E, Vuksan V, Jacobs R. 2008. Share and ShareAP investigators: Interrelation of saturated fat, trans fat, alcohol intake, and subclinical atherosclerosis. Am J Clin Nutr 87: 168-174.

Sartika RAD. 2008. Pengaruh asam lemak jenuh, tidak jenuh dan asam lemak trans terhadap kesehatan. J Kesehatan Masyarakat Nasional 2: 154-160.

Siri-Tarino PW, Sun Q, Hu FB, Krauss RM. 2010. Meta-analysis of prospective cohort studies evaluating the association of saturated fat with cardiovascular disease. Am J Clin Nutr 91: 535546. DOI: 10.3945/ajcn.2009.27725.

Song J, Park J, Jung J, Lee C, Gim SY, Ka H, Yi B, $\mathrm{Kim} \mathrm{MJ}$, Kim Cl, Lee JH. 2015. Analysis of trans fat in edible oils with cooking process. Toxicol Res 31: 307-312. DOI: 10.5487/TR. 2015.31.3.307.

Stachowska E, Jamiol D, Chlubek D. 2010. Trans fatty acids and their role in inflammation and cardiovascular disease. Ann Acad Med Stetin 56: 30-38.

Sun Q. 2007. Comparison between plasma and erythrocyte fatty acid content as biomarkers of fatty acid intake in US women. Am J Clin Nutr 86: 74-81.

Vahmani $\mathrm{P}$, Meadus WJ, Turner TD, Duff $\mathrm{P}$, Rolland DC, Mapiye C, Dugan MER. 2015. Individual trans 18:1 isomers are metabolised differently and have distinct effects on lipogenesis in 3T3L1 adipocytes. Lipids 50: 195-204. DOI: 10.1007/s11745-014-3982-8.

Xu J, Eilat-Adar S, Loria C, Coldbourt U, Howard BV, Fabsitz RR. 2006. Dietary fat intake and risk of coronary heart disease: the strong heart study. Am J Clin Nutr 84: 894-902.

Zhang Q, Qin W, Lin D, Shen Q, Saleh ASM. 2015. The changes in the volatile aldehydes formed during the deep-fat frying process. J Food Sci Technol 52: 763-769. DOI: 10.1007/s13197015-1923-z. 